RASĀYAN J. Chem.

Vol. 13 | No. 1 |160 - 167| January - March | 2020 ISSN: 0974-1496 | e-ISSN: 0976-0083 | CODEN: RJCABP

RJC http://www.rasayanjournal.com http://www.rasayanjournal.co.in

\title{
UNSYMMETRIC COMPARTMENTAL LIGANDS FOR METALLOBIOSITE MODELLING: A MINI REVIEW
}

\author{
Dipesh Ghosh \\ Department of Chemistry, Vivekananda Mission Mahavidyalaya, \\ Chaitanyapur, Haldia-721645, India \\ *E-mail: dipesh105@hotmail.com
}

\begin{abstract}
Studies on bimetallic complexes have received increasing attention recently because of their interesting physicochemical properties arising from the presence of two dissimilar metal ions in close proximity. Adjacent metal centers with hard-soft combination result co-operative effects that show unique reactivity patterns towards substrate molecules. New dinucleating ligands may be synthesized that feature two distinct binding pockets. These systems proved suitable for the preparation of unsymmetric bimetallic complexes in a controlled and predetermined fashion. This review describes the targeted synthesis, reactivity and structural properties of homo- and heterobinuclear complexes.

Keywords: Bridging ligands, Bimetallic Complexes, Metallobiosites, Metalloenzymes, Dinucleating Ligands, Transition Metals.
\end{abstract}

(C) RASĀYAN. All rights reserved

\section{INTRODUCTION}

Asymmetry plays an important role in biology because many active centers of metalloenzymes show unique properties due to co-operating unlike metal ions in close proximity. Binuclear sites of dissimilar metal ion combinations appear to control the functioning of enzymes under constraints of protein microenvironment due to their distinct chemical nature. This article describes the design and synthesis of new unsymmetric dinuclear systems that can have, in principle, asymmetric environments of three general types i.e. donor atom, coordination number or geometric asymmetry of either homo- or hetero-dinuclear character (Fig.-1). ${ }^{1}$

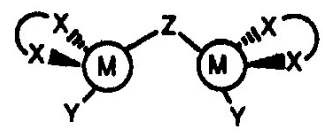

a) SYMMETRIC

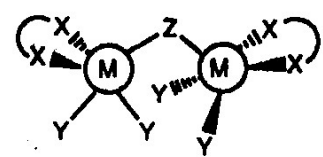

0) GEOMETRIC ASYMMETRY

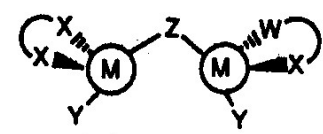

b) DONOR ASYMMETRY

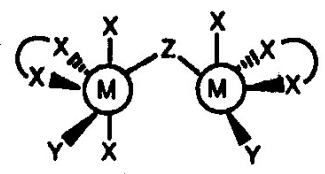

d) COOADINATION NUMBER ASYMMETRY

Fig.-1: Metal Coordination Environments present in Metallobiomolecules

\section{Understanding From Biology}

Biological problems related to reversible uptake and release of dioxygen in hemocyanine or the role of two nickel ions in urease catalyzing the hydrolysis of urea to ammonia and carbon dioxide as well as the Rasayan J. Chem., 13(1), 160-167(2020) http://dx.doi.org/10.31788/RJC.2020.1315586 
RASĀYAN J. Chem.

Vol. 13 | No. 1 |160 - 167| January - March | 2020

growing literature on the occurrence of dinuclear metallobiosites ${ }^{2}$ stimulated the interest of bioinorganic modelers to design functional model that simulate the natural site in terms of both structure and function. Synthetic models have been classified as speculative or corroborative. ${ }^{3}$ A speculative model is used to reproduce some spectroscopic property of the metallobiomolecule of unknown structure. A corroborative model is designed to replicate the coordination properties of a known structural site. Thus the relationship between coordination chemistry and bioinorganic chemistry may be thought of as synergistic (Fig.-2). ${ }^{4}$ This is an excellent example where biologists learning from chemistry and chemists applying knowledge concerning the structure of metalloprotein to develop new chemistry. To elucidate the latter part, the development of unsymmetric dinucleating ligands is important.

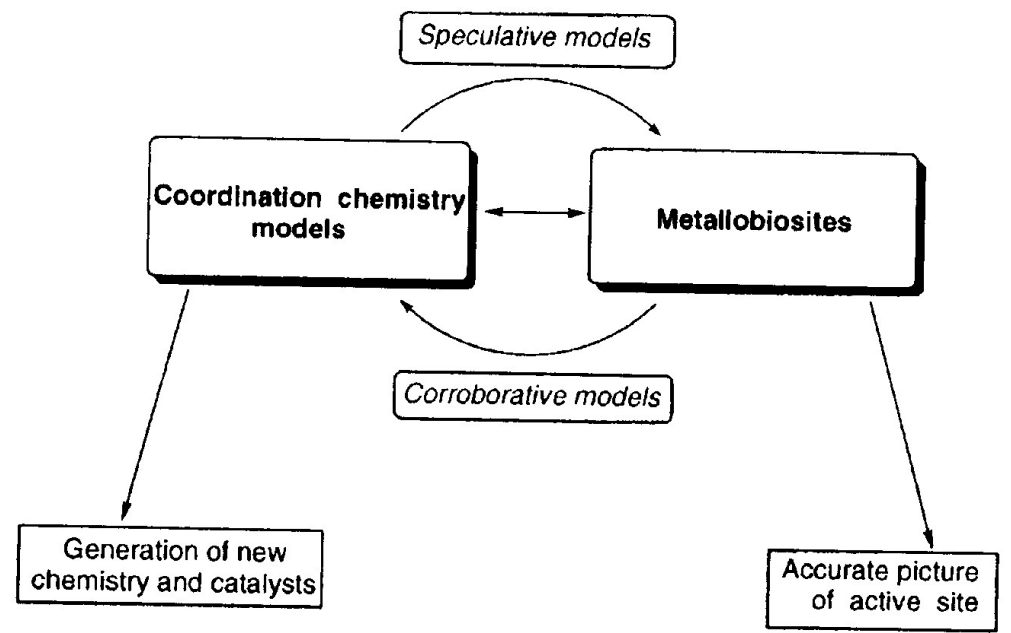

Fig.-2: The Synergism Between Coordination Chemistry and the Chemistry of Metallobiosites (Based on Ref. 4)

\section{Objective}

It is becoming increasingly more apparent that asymmetry in coordination environment may have significant role in imparting unique reactivity of metalloenzyme active sites ${ }^{5}$ as the binding and subsequent activation of the substrate by the enzyme necessitates its preferential attachment to one of the available metal centers, a prerequisite normally precluded in binuclear metalloorganic systems with symmetric, identical donor environments. Consequently, binuclear system with unsymmetrically disposed metal ion centers should be viewed as desirable synthetic targets to describe many metalloprotein binuclear active sites ${ }^{6}$. Although many of these model complexes derived unexpectedly from symmetric dinucleatng ligands ${ }^{7-11}$, polydentate ligands that would generate necessarily unsymmetrical, binuclear complexes remain rare. In fact, only a few systematic approaches with the rational design of ligand frameworks that could induce coordination asymmetry in binuclear complexes have been reported in recent time ${ }^{12-18}$. Homo- and heterobinucler metal complexes of biological relevance with different transition metal ions such as nickel(II), copper(II) zinc(II) etc. and some other 4d-transition metal ions with unsymmetric dinucleating "end off" models to understand the biological function of the bimetallic cores in metalloproteins. Furthermore, the perception that the binuclear active sites of many metalloenzyme situate their metal centers in chemically distinct environments has inspired coordination chemists to generate new coordination chemistry with binuclear compounds in unsymmetrical ligand environment. In addition, X-ray crystallography, EPR and electronic spectroscopy magnetic measurement etc. of the synthetic analogs serve to act as a guide to elucidate fundamental aspects pertaining to the metal-containing site.

\section{Research and Development in the Subject}

Since 1990 much progress has been made in the synthesis of dinucleating ligands with built-in asymmetric features. A common motif in the design of dinucleating ligands involves an alkoxide/phenoxide or pyrazolate group with pendant polyamino side arms that bridges the two metal 
RASĀYAN J. Chem.

Vol. 13 | No. 1 |160 - 167| January - March | 2020

centers, and the remainder of the ligand construct usually requires further coordinating groups to retain the metal atoms and prevent the formation of multinuclear arrays. In the international arena, a few groups of eminent scientists are pursuing this emerging field with much zeal and success. Ōkawa et al ${ }^{20-28}$ focused mainly on phenol based "end-off" compartmental ligands possessing chelating arms attached to the 2 and 6 positions of the phenolic ring (Fig.-3) have often been used for model studies of bimetallic biosites. Recently ${ }^{29}$, type $B$ ligand is used to obtain heterodinuclear complexes $\left[\mathrm{M}_{\mathrm{a}} \mathrm{M}_{\mathrm{b}}(\mathrm{L})(\mathrm{AcO})_{2}\right]^{+}$(where $\mathrm{HL}=2-\{\mathrm{N}-[2-($ dimethylamino$)$ ethyl]iminomethyl $\}-6-[\mathrm{N}, \mathrm{N}-\mathrm{di}(2-$ pyridylmethyl)aminomethyl]-4methylphenol, $\mathrm{M}_{\mathrm{a}}=\mathrm{Cu}^{\mathrm{II}}$ and $\mathrm{M}_{\mathrm{b}}=\mathrm{Mn}^{\mathrm{II}}, \mathrm{Fe}^{\mathrm{II}} \mathrm{Co}^{\mathrm{II}}, \mathrm{Ni}^{\mathrm{II}}, \mathrm{Zn}^{\mathrm{II}} ; \mathrm{M}_{\mathrm{a}}=\mathrm{Zn}^{\mathrm{II}}$ and $\left.\mathrm{M}_{\mathrm{b}}=\mathrm{Co}^{\mathrm{II}}, \mathrm{Ni}^{\mathrm{II}}\right)$ in one-pot reaction. The site-specificity of metal ions is associated with the ligand $\mathrm{L}^{-}$providing a five-coordinate geometry for the $\mathrm{M}_{\mathrm{a}}$ bound to the bidentate arm and six-coordinate geometry for $\mathrm{M}_{\mathrm{b}}$ bound to the tridentate arm.<smiles>[X]CC/N=C\c1cc(C)cc(/C=N\CC[X])c1[O-]</smiles>

Fig.-3: Various Unsymmetric “End-Off” Proligands

Krebs and his co-workers ${ }^{17,30}$ employed endogenous alkoxo-bridged ligands to synthesize dinuclear nickel(II) complexes as models for the active site of urease. The asymmetric complex ${ }^{17}$ in Fig. 4 was prepared in order to mimic the substrate uptake in the dinuclear active site of ureases.
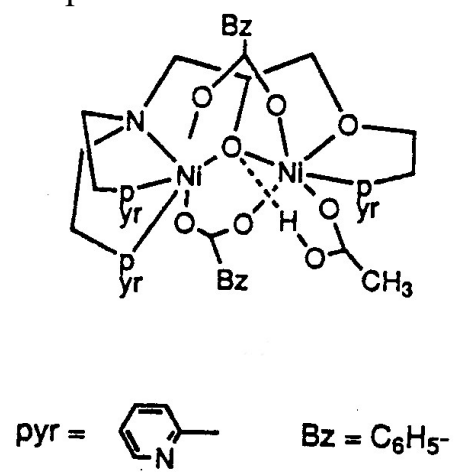

Fig.-4: Biomimetic Model for Urease (Reprinted with Permission from Ref. 6f, Copyright ACS)

Latour et al. reported mix-valance $\mathrm{Fe}^{\mathrm{II}} \mathrm{Fe}^{\mathrm{III}}$ complexes of an asymmetrical phenolate ligand ${ }^{12,31,32}$ that mediates intramolecular hydroxylation of a dangling benzyl residue of the ligand almost quantitatively in the presence of an oxygen donor to give ortho-hydroxybenzyl group (Fig.-5). Experimental evidence suggests a oxodiiron(IV) species is presumably the key intermediate. There is no published report of oxo$\mathrm{Fe}^{\mathrm{IV}} \mathrm{Fe}^{\mathrm{IV}}$ compound. This reactivity bears a strong resemblance to the toluene-2-monooxyenase $e^{33}$, which is structurally similar to methane monooxygenase.

In contrast to the many dinuclear complexes based on compartmental phenolate or alkoxide ligand matrices, however, examples of unsymmetrical systems of pyrazolate ligands providing additional chelating substituents particularly in the 3- and 5- positions of the heterocycle (Fig.-6) remained relatively rare, ${ }^{34-48}$ despite their being attractive targets for controlled synthesis of heterobimetallic complexes. A major reason for this is the lack of readily available functional pyrazole derivatives that might provide a straightforward and high-yielding route for the attachment of various donor side arms. Meyer and his 
RASĀYAN J. Chem.

Vol. 13 | No. 1 | 160 - 167| January - March | 2020

group have published ${ }^{44}$ a synthetic route opening up access to various unsymmetric pyrazolate-based ligand systems with variable chelating side arms (Scheme-1).
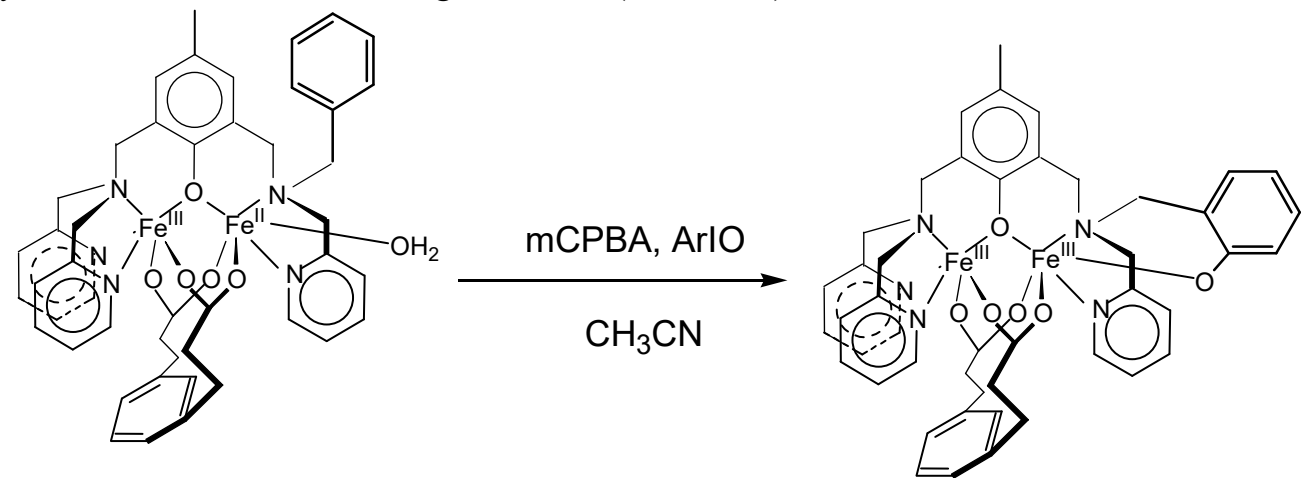

Fig.-5: Intramolecular Aromatic Hydroxylation

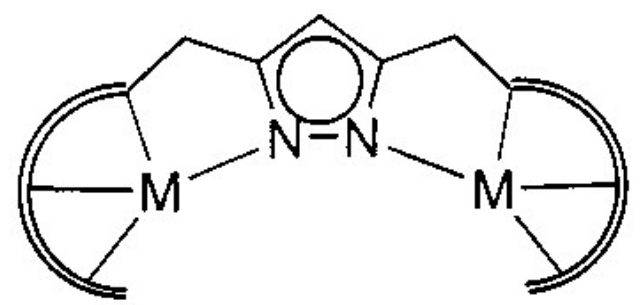

Fig.-6: Dinucleating Pyrazolate Ligands with Dissimilar Chelating Side Arms

Recently we prepared heterodinuclear complexes of $\mathrm{Cu}$ (II)/Co(II) combinations (Fig.-7) using the dinucleating asymmetric ligands containing N/S donor by a convenient single-pot synthetic procedure (unpublished results).

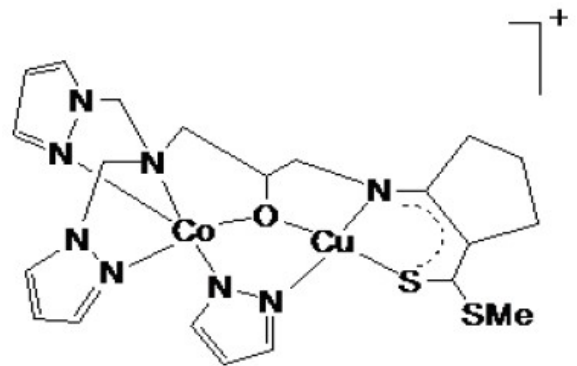

Fig.-7: $\mu$-Alkoxo- $\mu$-pyrazolato $\mathrm{Cu}(\mathrm{II})-\mathrm{Co}(\mathrm{II})$ Heterodinuclear Complex

It is an upcoming area in contemporary co-ordination chemistry research and contribution from India is limited. ${ }^{49-51}$

\section{Pyrazolate-Bridge Ligands}

The present review focuses on the synthesis of binuclear transition metal complexes of both homo- and heterometal combinations. The phenolate and alkoxide bridges are generally the least challenging as they have been extensively studied. So we have chosen binucleating pyrazolate bridging ligands with different chelating side arms in the 3 and 5 positions of the heterocycle. The negatively charged pyrazolate bridge can form five- or six-membered bimetallic ring systems without significant strain (Fig.-8). Usually, the metal-metal separation in these systems ranges from about 3.5 to $4.0 \AA$. Binucleating pyrazolate ligands can form either bis- or monopyrazolate systems (Fig.-9). In the latter case, the di-metal ring is completed by the introduction of an exogenous bridging ligand, X. Although the pyrazolate bridge has several attractive features, including its stability, strainless formation of bimetallic complexes, and resemblance 
RASĀYAN J. Chem.

Vol. 13 | No. 1 | 160 - 167| January - March | 2020

to imidazoles, the synthesis of pyrazole ligands is not an arduous exercise because of the inherent difficulties in the preparation of such ligands. Unsymmetrically substituted pyrazole derivative (II) can be prepared by the cycloaddition procedure ${ }^{52}$ (Scheme-1).

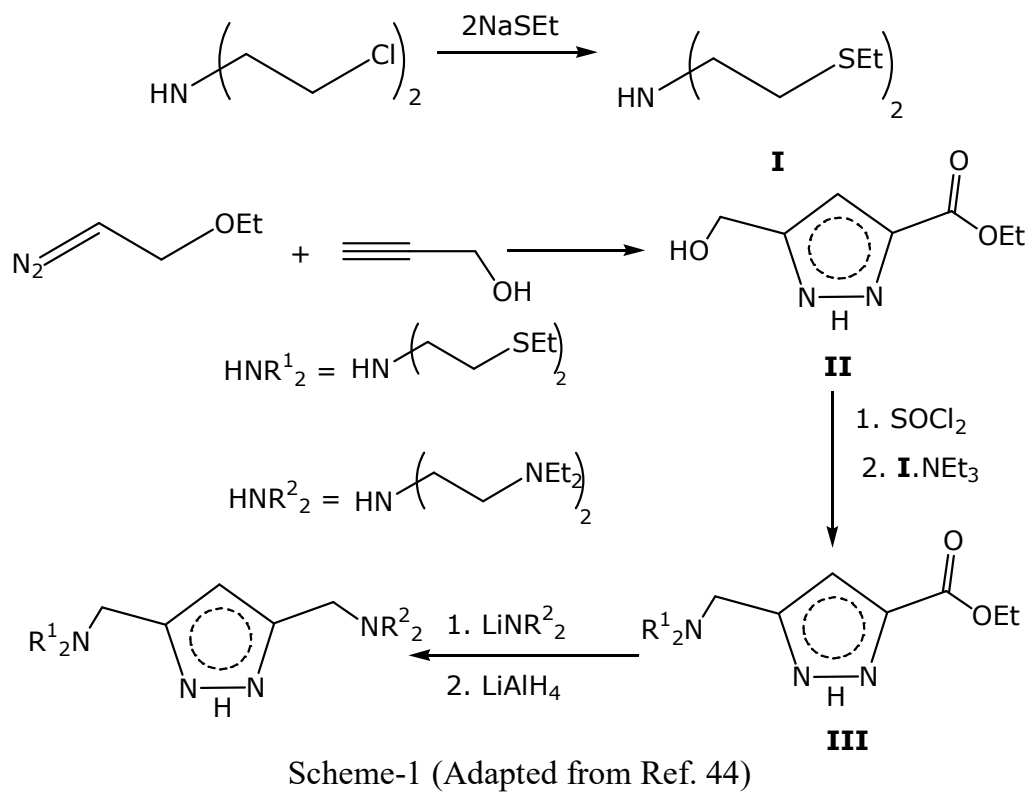

The alcohol and ester groups will be manipulated separately to generate unsymmetrical binucleating ligands. Metal ions, viz. $\mathrm{Cu}(\mathrm{II}), \mathrm{Ni}(\mathrm{II}), \mathrm{Zn}(\mathrm{II}), \mathrm{V}(\mathrm{IV} / \mathrm{V}), \mathrm{Fe}(\mathrm{II} / \mathrm{III})$ and $\mathrm{Mn}(\mathrm{II} / \mathrm{III} / \mathrm{IV})$ can be chosen in various combinations for the synthesis of bimetallic structures with interesting spectroscopic, redox and magnetic properties. Some of the target molecules are expected to have the following combinations of metal centers:

i. $\quad$ Synthesis of magnetically coupled binuclear compounds involving $\mathrm{Cu}(\mathrm{II})-\mathrm{M}(\mathrm{II})(\mathrm{M}=\mathrm{V}(\mathrm{IV})$, $\mathrm{Mn}(\mathrm{II}), \mathrm{Co}(\mathrm{II}), \mathrm{Cu}(\mathrm{II})$ etc.) combinations

ii. $\quad$ Controlled synthesis of homobimetallic mixed-spin complexes.

iii. Synthetic dizinc complexes to develop a new catalytic process that is beyond the scope of natural enzymes

iv. Phenol oxidation reactions with dicopper complexes, where often only one of the copper ions is redox-active
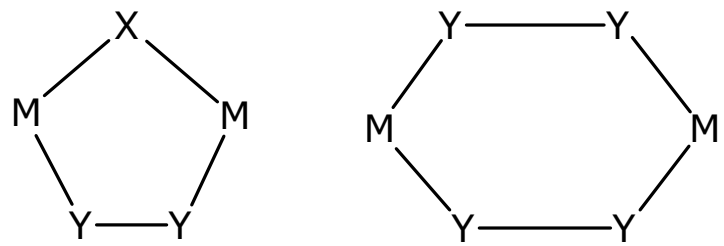

Fig.-8: The Bridging Structures Formed without Significant Strain

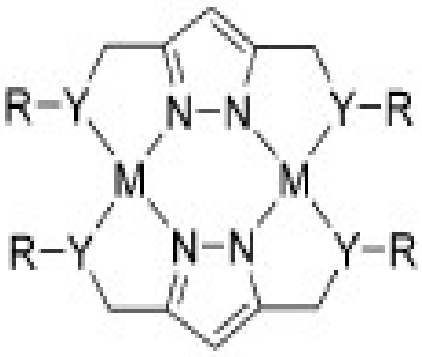

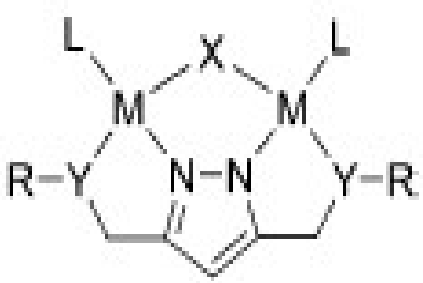

Fig.-9: Bispyrazolate and Monopyrazolate Systems 
RASĀYAN J. Chem.

Vol. 13 | No. 1 |160 - 167| January - March | 2020

\section{CONCLUSION}

Biological relevance and applications of transition metal complexes are well documented. ${ }^{53-55}$ Binuclear complexes have attracted particular interests focused on the modeling of metallobiosites and on the cooperativity of the neighboring metals in promoting reactions. ${ }^{56}$ Cooperative interactions between the two adjacent metal centers are important in bioinorganic model studies, organic synthesis and catalysis and give rise to interesting physicochemical properties. ${ }^{49-51,56-67}$ It is evident that the use of small-molecule model compounds can provide useful information in understanding biological functions and the mechanistic pathway of the bimetallic cores. This is a budding area of coordination chemistry with respect to ligand design and synthesis as well as in the application of the formed dinuclear complexes, as speculative, and to an extent corroborative, a model for binuclear metal centers. Comparison of the physicochemical properties of the asymmetric complexes with those of their symmetric parent complexes can give insight into the fine-tuning available from subtle changes in ligation at binuclear centers.

\section{ACKNOWLEDGMENT}

Financial assistance received from UGC MRP No. F. PSW-233/15-16(ERO) dated 21.11.2016, is gratefully acknowledged. Thanks to Professor M. Chaudhury, Retired Senior Professor, IACS, Kolkata for useful discussions.

\section{REFERENCES}

1. J.H. Satcher, Jr., M.W. Droege, T.J.R. Weakley and R.T. Taylor, Inorganic Chemistry, 34, 3317(1995), DOI:10.1021/ic00116a026

2. D.E. Fenton, Advances in Inorganic and Bioinorganic Mechanisms, 2, 187(1983).

3. H.A.O. Hill, Chemistry in Britain, 12, 119(1976).

4. D.E. Fenton, Chemical Society Reviews, 28, 159(1999), DOI: 10.1039/A805645E

5. H. Deng and R. Hoffmann, Angewandte Chemie International Edition in English, 32, 1062(1993), DOI:10.1002/anie.199310621

6. T.N. Sorrell, Tetrahedron, 45, 3(1989), DOI:10.1016/0040-4020(89)80033-X

7. R.E. Norman, S. Yan, L. Que, Jr., G. Backes, J. Ling, J. Sanders-Loehr, J.H. Zhang and C.J. O'Connor, Journal of the American Chemical Society, 112, 1554(1990), DOI: $10.1021 /$ ja00160a039

8. W.B. Tolman, S. Liu, J.G. Bentsen and S.J. Lippard, Journal of the American Chemical Society, 113, 152(1991), DOI:10.1021/ja00001a023

9. Y. Hayashi, M. Suzuki, A. Uehara, Y. Mizutani and T. Kitagawa, Chemistry Letters, 21, 91 (1992), DOI:10.1246/cl.1992.91

10. M. Corbella, R. Costa, J. Ribas, P.H. Fries, J.-M. Latour, L. Öhrström, X. Solans and V. Rodriguez, Inorganic Chemistry, 35, 1857(1996), DOI:10.1021/ic950930x

11. P. Gomez-Romero, E.H. Witten, W.M. Reiff, G. Backes, J. Sanders-Loehr and G.B. Jameson, Journal of the American Chemical Society, 111, 9039(1989), DOI:10.1021/ja00207a009

12. W. Kanda, W. Moneta, M. Bardet, E. Bernard, N. Debaecker, J. Laugier, A. Bousseksou, S. Chardon-Noblat and J.-M. Latour, Angewandte Chemie International Edition in English, 34, 588(1995), DOI:10.1002/anie.199505881

13. P. Kamaras, M.C. Cajulis, M. Rapta, G.A. Brewer and G.B. Jameson, Journal of the American Chemical Society, 116, 10334(1994), DOI:10.1021/ja00101a077

14. E. Bernard, W. Moneta, J. Laugier, S. Chardon-Noblat, A. Deronzier, J.-P. Tuchagues and J.-M. Latour, Angewandte Chemie International Edition in English, 33, 887(1994), DOI: 10.1002/anie.199408871

15. J.H. Satcher, A.L. Balch, M.M. Olmstead and M.W. Droege, Inorganic Chemistry, 35, 1749(1996), DOI:10.1021/ic9511711

16. H. Adams, G. Candeland, J.D. Crane, D.E. Fenton and A.J. Smith, Journal of the Chemical Society, Chemical Communications, 93(1990), DOI:10.1039/C39900000093

17. D. Volkmer, A. Hörstmann, K. Griesar, W. Haase and B. Krebs, Inorganic Chemistry, 35, 1132(1996), DOI:10.1021/ic950368a

18. M.S. Nasir, K.D. Karlin, D. McGowty and J. Zubieta, Journal of the American Chemical Society, 
RASĀYAN J. Chem.

Vol. 13 | No. 1 |160 - 167| January - March | 2020

113, 698(1991), DOI:10.1021/ja00002a062

19. J. D. Crane, D. E. Fenton, J. M. Latour and A. J. Smith, Journal of the Chemical Society, Dalton Transactions, 2979(1991), DOI:10.1039/DT9910002979

20. H. Sakiyama, H. Ōkawa and R. Isobe, Journal of the Chemical Society, Chemical Communications, 882(1993), DOI:10.1039/C39930000882

21. H. Sakiyama, H. Tamaki, M. Kodera, N. Matsumoto and H. Ōkawa, Journal of the Chemical Society, Dalton Transactions, 591(1993), DOI:10.1039/DT9930000591

22. H. Sakiyama, H. Ōkawa and M. Suzuki, Journal of the Chemical Society, Dalton Transactions, 3823(1993), DOI:10.1039/DT9930003823

23. C. Higuchi, H. Sakiyama, H. Ōkawa, R. Isobe and D.E. Fenton, Journal of the Chemical Society, Dalton Transactions, 1097(1994), DOI:10.1039/DT9940001097

24. C. Higuchi, H. Sakiyama, H. Ōkawa and D.E. Fenton, Journal of the Chemical Society, Dalton Transactions, 4015(1995), DOI:10.1039/DT9950004015

25. K. Abe, J. Izumi, M. Ohba, T. Yokoyama and H. Ōkawa, Bulletin of the Chemical Society of Japan, 74, 85(2001), DOI:10.1246/bcsj.74.85

26. M. Suzuki, H. Furutachi and H. Ōkawa, Coordination Chemistry Reviews, 200-202, 105(2000), DOI:10.1016/S0010-8545(00)00323-4

27. T. Koga, H. Furutachi, T. Nakamura, N. Fukita M. Ohba, K. Takahashi and H. Ōkawa, Inorganic Chemistry, 37, 989(1998), DOI:10.1021/ic971209p

28. S. Uozumi, H. Furutachi, M. Ohba, H. Ōkawa, D.E. Fenton, K. Shindo, S. Murata and D.J. Kitko, Inorganic Chemistry, 37, 6281(1998), DOI:10.1021/ic9807689

29. K. Abe, K. Matsufuji, M. Ohba and H. Ōkawa, Inorganic Chemistry, 41, 4461(2002), DOI: $10.1021 / \mathrm{ic} 020002 \mathrm{f}$

30. D. Volkmer, B. Hommerich, K. Griesar, W. Haase and B. Krebs, Inorganic Chemistry, 35, 3792(1996), DOI:10.1021/ic951567x

31. S. Chardon-Noblat, O. Horner, B. Chabut, F. Avenier, N. Debaecker, P. Jones, J. Pécaut, L. Dubois, C. Jeandey, J.L. Oddou, A. Deronzier and J.M. Latour, Inorganic Chemistry, 43, 1638(2004), DOI:10.1021/ic030192+

32. F. Avenier, L. Dubois and J.M. Latour, New Journal of chemistry, 28, 782(2004), DOI: 10.1039/B402403F

33. L.M. Newman and L.P. Wackett, Biochemistry, 34, 14066(1995), DOI:10.1021/bi00043a012

34. T.G. Schenck, J.M. Downes, C.R.C. Milne, P.B. Mackenzie, T.G. Boucher, J. Whelan and B. Bosnich, Inorganic Chemistry, 24, 2334(1985), DOI:10.1021/ic00209a003

35. T. Kamiusuki, H. Okawa, E. Kitaura, M. Koikawa, N. Matsumoto, S. Kida and H. Oshio, Journal of the Chemical Society, Dalton Transactions, 2077(1989), DOI:10.1039/DT9890002077

36. T. Kamiusuki, H. Okawa, N. Matsumoto and S. Kida, Journal of the Chemical Society, Dalton Transactions, 195(1990), DOI:10.1039/DT9900000195

37. T. Kamiusuki, H. Okawa, K. Inoue, N. Matsumoto, M. Kodera and S. Kida, Journal of Coordination Chemistry, 23, 201(1991), DOI:10.1080/00958979109408251

38. M. Itoh, K. Motoda, K. Shindo, T. Kamiusuki, H. Sakiyama, N. Matsumoto and H. Okawa, Journal of the Chemical Society, Dalton Transactions, 3635(1995), DOI:10.1039/DT9950003635

39. B. Mernari, F. Abraham, M. Lagrenee, M. Drillon and P. Legoll, Journal of the Chemical Society, Dalton Transactions, 1707(1993), DOI:10.1039/DT9930001707

40. L. Behle, M. Neuburger, M. Zehnder and T.A. Kaden, Helvetica Chimica Acta, 78, 693(1995), DOI:10.1002/hlca.19950780316

41. J. Pons, X. López, E. Benet, J. Casabó, F. Teixidor and F. J. Sánchez, Polyhedron, 9, 2839(1990), DOI: $10.1016 / \mathrm{S} 0277-5387(00) 84188-1$

42. J. Pons, F. J. Sánchez, A. Labarta, J. Casabó, F. Teixidor and A. Caubet, Inorganica Chimica Acta, 208, 167(1993), DOI: 10.1016/S0020-1693(00)85117-8

43. F. Meyer, S. Beyreuther, K. Heinze and L. Zsolnai, Chemische Berichte/Recueil, 130, 605(1997), DOI:10.1002/cber.19971300511

44. M. Konrad, F. Meyer, K. Heinze and L. Zsolnai, Journal of the Chemical Society, Dalton 
RASĀYAN J. Chem.

Vol. 13 | No. 1 |160 - 167| January - March | 2020

Transactions, 199(1998), DOI:10.1039/A705543I

45. F. Meyer, A. Jacobi and L. Zsolnai, Chemische Berichte/Recueil, 130, 1441(1997), DOI:10.1002/cber.19971301014

46. V.P. Hanot, T.D. Robert, J. Kolnaar, J.G. Haasnoot, J. Reedijk, H. Kooijman and A.L. Spek, Journal of the Chemical Society, Dalton Transactions, 4275(1996), DOI:10.1039/DT9960004275

47. P.L. Jones, J.C. Jeffery, J.A. McCleverty and M.D. Ward, Polyhedron, 16, 1567(1997), DOI: 10.1016/S0277-5387(96)00457-3

48. J.C. Jeffery, P.L. Jones, K.L.V. Mann, E. Psillakis, J.A. McCleverty, M.D. Ward and C.M. White, Chemical Communications, 175(1997), DOI:10.1039/A606827H

49. B. Dutta, P. Bag, U. Flörke and K. Nag, Inorganic Chemistry, 44, 147(2005), DOI: $10.1021 /$ ic049056a

50. K. Shanmuga Bharathi, A. Kalilur Rahiman, K. Rajesh, S. Sreedaran, P.G. Aravindan, D. Velmurugan and V. Narayanan, Polyhedron, 25, 2859 (2006), DOI:10.1016/j.poly.2006.04.022

51. P. Biswas, M. Ghosh, S.K. Dutta, U. Flörke and K. Nag, Inorganic Chemistry, 45, 4830(2006), DOI: $10.1021 /$ ic $060183 b$

52. E. Mugnaini and P. Grünanger, Atti della Accademia Nazionale dei Lincei. Classe di Scienze Fisiche, Matematiche e Naturali. Rendiconti, 14, 958(1953).

53. D. Mandal and B. Mandal, Rasayan Journal of Chemistry, 12, 754(2019), DOI: 10.31788/RJC.2019.1225230

54. M.M. El-ajaily, A.A. Maihub, U.K. Mahanta, G. Badhei, R.K. Mohapatra and P. K. Das, Rasayan Journal of Chemistry, 11, 166(2018), DOI:10.7324/RJC.2018.1111988

55. A. Wajid and R.B. Mohod, Rasayan Journal of Chemistry, 6, 284(2013).

56. A.L. Gavrilova and B. Bosnich, Chemical Reviews, 104, 349(2004), DOI:10.1021/cr020604g

57. G. Paulucci, P.A. Vigato, G. Rossetto and U. Casellato, Inorganica Chimica Acta, 65, L71(1982), DOI: 10.1016/S0020-1693(00)93498-4

58. L. Xiaozeng, W. Genglin, L. Daizheng, Y. Shiping, J. Zonghui, W. Honggeh and Y. Xinkan Polyhedron, 14, 511(1995), DOI:10.1016/0277-5387(94)00269-K

59. P. Cheng, D. Liao, S. Yan, Z. Jiang and G. Wang, Polyhedron, 14, 2355(1995), DOI:10.1016/0277-5387(95)00062-W

60. M. Mikuriya and S. Tashima, Polyhedron, 17, 207(1998), DOI:10.1016/S0277-5387(97)00255-6

61. A. Erxleben, Inorganic Chemistry, 40, 208(2001), DOI:10.1021/ic000600z

62. H. Adams, D. Bradshaw and D.E. Fenton, Polyhedron 21, 1957(2002), DOI:10.1016/S02775387(02)01099-9

63. H. Adams, D. Bradshaw and D.E. Fenton, Inorganica Chimica Acta, 332, 195(2002), DOI: 10.1016/S0020-1693(02)00706-5

64. B.-H. Ye, X.-Y. Li, I.D. Williams and X.-M. Chen, Inorganic Chemistry, 41, 6426(2002), DOI: $10.1021 /$ ic025806+

65. H. Adams, L.R. Cummings, D.E. Fenton and P.E. McHugh, Inorganic Chemistry Communications, 6, 19(2003), DOI:10.1016/S1387-7003(02)00676-7

66. G. Ambrosi, M. Formica, V. Fusi, L. Giorgi, A. Guerri, M. Micheloni, P. Paoli, R. Pontellini and P. Rossi, Inorganic Chemistry, 46, 309(2007), DOI:10.1021/ic061474n

67. D.J. Doyle, V.C. Gibson and A.J.P. White, Dalton Transactions, 358(2007), DOI:10.1039/B615080B

[RJC-5586/2019] 